\title{
Comparative and legal analysis of the legislation of Ukraine and the European Union in the field of organic production of livestock
}

\author{
K.O. Rodionova1 , O.S. Nihmatova², M.S. Khimych¹, V.M. Steshenko³, M.M. Broshkov1, A.P. Paliy ${ }^{4,5}$, \\ I.V. Yatsenko 6 , A.P. Palii ${ }^{5}$ \\ ${ }^{1}$ Odessa State Agrarian University, 13 Panteleimonovskaya St, Odessa, Ukraine ,65012 \\ 2 Public Association "Federation of Auditors, Accountants and Financiers of Agro-Industrial Complex" \\ 37/1, Tankopiya Str., Kharkiv, Ukraine, 61099 \\ ${ }^{3}$ Yaroslav Mudryi National Law University, 77 Pushkinska St, Kharkiv, Ukraine, 61024 \\ ${ }^{4}$ National Scientific Center "Institute of Experimental and Clinical Veterinary Medicine" \\ 83 Pushkinska St, Kharkiv, Ukraine, 61023 \\ ${ }^{5}$ Kharkiv National Technical University of Agriculture named after Petro Vasylenko \\ 44 Alchevskih St, Kharkiv, Ukraine, 61002 \\ ${ }^{6}$ Kharkiv State Zooveterinary Academy, 1 Akademicheskaya St, village Malaya Danilovka, Dergachevskyi \\ district, Kharkiv region, Ukraine, 62341 \\ ${ }^{7}$ Altai State University, 61 Lenin St, Barnaul, Russian Federation \\ *Corresponding authorE-mail: katerina.rodionova@ukr.net
}

Received: 01.11.2020. Accepted 07.12.2020

The aim of the work has been to determine the correspondence of the content of the current legislation of Ukraine to the EU regulations according to quality assurance of organic livestock production and to identify specific areas of national legal support that need to be improved in order to adapt to respective European standards. The main EU regulations in the field of production of organic livestock products are considered in the paper, the main principles of normative-legal acts of our state, which regulate this sphere, are considered. The light was throun on the problematic issues of adaptation of the national legislation of Ukraine to the EU regulations in the field of production and circulation of organic products. The need to improve the legislation of Ukraine in specific areas in accordance with European requirements is substantiated.

Keywords: organic, production, organic products market, organic livestock products, animal welfare, EU regulations, adaptation of Ukrainian legislation.

\section{Introduction}

At this juncture the current global trend is the promotion of a healthy lifestyle, increasing demand for organic products, in particular, of animal origin. At the same time, the environmental awareness of consumers is growing. It embodies the desire to ensure animal health and welfare in agriculture (Husic-Mehmedovic et al., 2017). Hence, the development of organic livestock production for the agricultural sector of national economies of many countries is considered as promising one. After all, this type of entrepreneurial economic activity is one where the desire to make a profit is based on environmental protection, animal welfare and public good by producing safe food (Reganold \& Wachter, 2016; Milovanov, 2019; Paliy et al., 2020a).

Methods of organic production in the field of animal husbandry are allocated in special standards and provide not only the maximum use of environmentally friendly technologies that ensure high product quality, but also ethical treatment to animals, taking into account their specific behavioral needs during rising, breeding and treatment (Escribano, 2016; Seufert et al., 2017; Paliy et al., 2020b).

In the process of production of organic livestock products waste from livestock farms is used. This in its turn reduces the dependence of producers on synthetic additives, and also provides for the standardization of the use of manure to grow crops, which reduces the level of environmental pollution (Nazarenko et al., 2020). Based on these characteristics, such production is close to the goals of sustainable development and meets the aspirations of environmentally conscious consumers (Ulko, 2019). 
Currently, the production of organic products is developing in 186 countries, and the global market for such products reaches 96.6 billion euros. Global trends in the consumption of organic products show an annual growth of an average of 5.7 billion euros or 12\%. There are 2.8 million organic producers worldwide, using a total of 71.8 million hectares of certified land (Willer et al., 2020).

The European Union (hereinafter - the EU) is one of the largest markets for organic products. Over the past two decades there is the high rate of spread of organic production in the EU member states. It is, in particular, due to the established system of regulations in this sector, which is reflected in the legislative principles, rules, requirements and procedures for production and circulation of organic products, structure and powers of control and certification authorities in order to organize and streamline the activities of economic entities in this area. The general purpose of regulations is to maintain and improve the quality of production of organic livestock products, to ensure compliance of the process of its production and circulation with organic standards, providing appropriate guarantees to consumers. The presence of regulations is a prerequisite for a more transparent organic market and the confidence of trading parties (Milovanov, 2018; Dayoub \& Korpela, 2019).

Ukraine, having significant potential to produce organic livestock products, exports and consumption in the domestic market, has achieved some results in the organic production sector, but the direction of organic livestock is underdeveloped. The introduction of organic production methods in our country began in the late 90 s of the twentieth century, but only by 2020 the regulatory support for the functioning of the organic sector of agriculture is in its final stages of formation.

Ukraine's European integration aspirations determine the gradual complience of the national system of regulation of relations in the organic sector to the requirements and standards of the EU. However, the process of Ukraine's European integration in this area is very slow, as the rules and requirements for the production of organic products, including the animal origin production, in the EU are being systematically improved (in order to get closer to sustainable development), while Ukraine is just beginning the development of organic legislation (Rodionova et al., 2020).

It should be noted that the EU is a key trading partner for Ukraine. About $80 \%$ of all organic plant agricultural raw materials produced in Ukraine are exported to EU countries (Information web portal OrganicInfo, 2019). Gradually, the Ukrainian market is filled with finished organic products from European manufacturers (Airapetov et al., 2017).

Thus, legal norm of regulation and control of compliance with the rules and principles of organic production is relevant for Ukraine. And watching and taking into account the trends in EU legislation are key to adapt the national legislation of Ukraine and creat a competitive domestic production of organic livestock products.

The purpose of the work is to clarify the compliance of the content of legal regulation of Ukraine with the requirements of the European Union to ensure the quality of production of organic livestock products and provide proposals to improve national legislation to adapt to relevant EU standards.

Adaptation of Ukrainian legislation to EU legislation in such areas as protection of human health and life, animals and plants one as well as consumer protection is provided in the State Program for Adaptation of Ukrainian Legislation to the Legislation of the European Union, which is approved by the Law of Ukraine of 18 March 2004 No 1629-IV and in the Association agreement between the European Union and its Member States, of the one part, and Ukraine, of the other part (2014).

\section{Materials and methods}

The study was carried out at the Department of International Law of the Yaroslav Mudryi National Law University (Kharkiv), the Department of Veterinary Hygiene, Sanitation and Expertise of Odessa State Agrarian University (Odessa) and the Bureau of Forensic Veterinary Research of Kharkiv State Veterinary Academy (Kharkiv).

The objects of research are the legal acts of the current legislation of Ukraine and the European Union, which provide the process of organic production of livestock products.

The methodological basis of the study is a set of general and special methods of cognition of legal phenomena. The formallegal method was chosen to establish the content of certain principles of the legislation governing the organic production of livestock products in Ukraine and in the EU. The comparative-legal method was used to compare some provisions of Ukrainian legislation in the field of organic livestock production to EU legislation and identify specific areas in the national legal framework for the production of organic livestock products that do not respond to EU regulations. Analysis and synthesis have been used to study the potential negative consequences in terms of values and principles of organic production. The modeling method was used during the development of amendments to the current legislation of Ukraine in the field of organic production of livestock products.

\section{Results and discussion}

\section{General statistical characteristics of organic production in the EU and Ukraine}

According to the report 'The World of Organic Agriculture Statistics and Emerging Trends 2020', which is prepared in 2020, the Research Institute of Organic Agriculture (FiBL) and the International Federation of Organic Agriculture Movements (IFOAM), in 2018 the EU is the second largest market for organic products with a sales share of $39 \%$ of world volume after the United States. In 2018, the EU market amounted to 37.4 billion euros, an increase of $7.7 \%$ compared to 2017 (Willer et al., 2020).

Since 2004, the moment of the largest enlargement of the EU in terms of human and territorial indicators, until 2018, there has been a positive dynamics of growth in the market for sales of organic products by an average of $9.7 \%$ annually (Fig. 1). At the same time, the sales growth rate is uneven over the years and shows significant fluctuations. The largest increase in sales of organic products in the EU occurred in 2006 - by 18.6\% compared to 2005, the smallest in 2009 - by 3.7\% compared to 2008. 


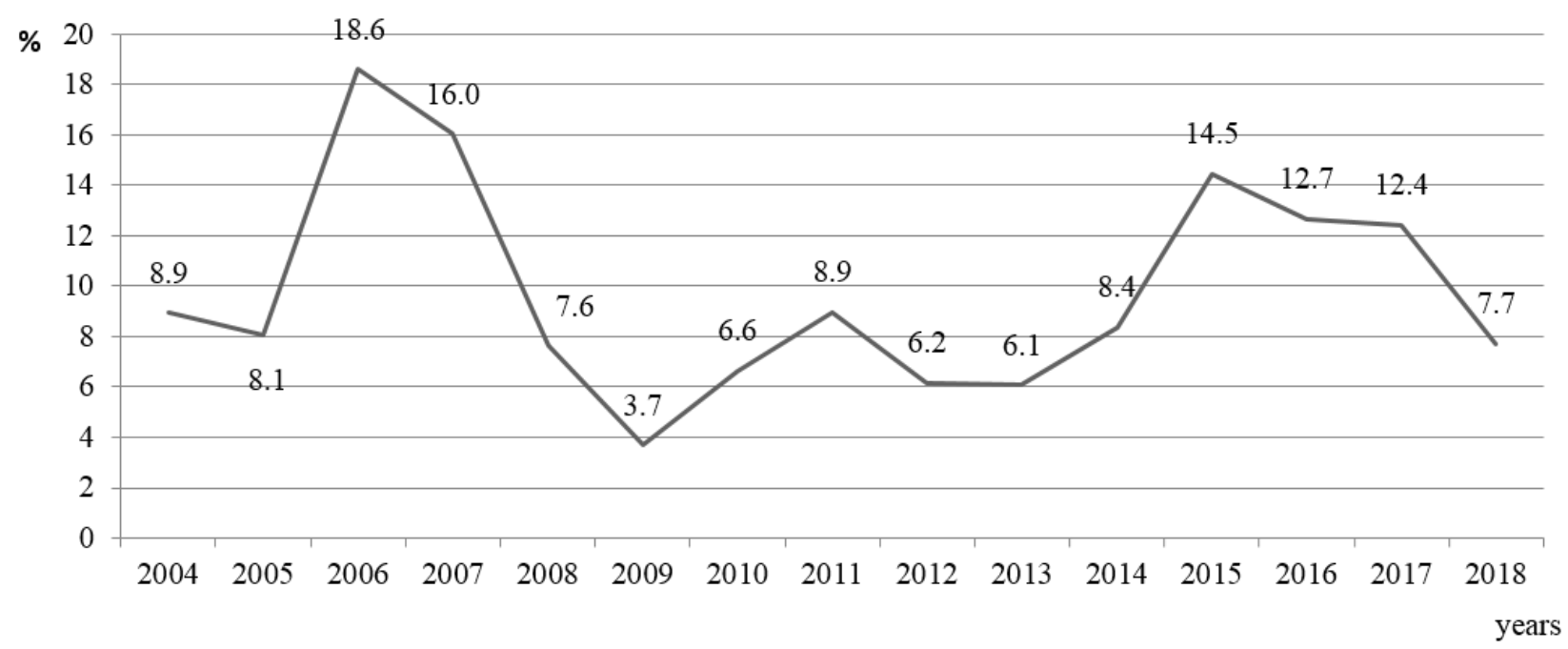

Fig. 1. Growth rate of sales of organic products in the EU in the period 2004-2018, \%

Source: built by the authors based on statistics Research Institute of Organic Agriculture (FiBL).

The EU countries which have the largest markets of organic products in 2018 were Germany (10.9 billion euros - $29.1 \%$ ), France (9.1 billion euros - 24.3\%), Italy (3.4 billion euros - 9.1\%), Sweden (2.3 billion euros - 6.1\%), Spain (1.9 billion euros - 5.1\%), where most of the consumption of organic products in the EU is consumed (73.7\%) (Willer et al., 2020).

The constantly increasing demand in organic products is leading to growth in organic production, attracting the attention of more and more supporters from agricultural producers. In the EU countries alone, the amount of organic land in 2018 amounted to 13.8 million hectares, which is 7.6\% more than in 2017. In general, over the past 10 years, organic land in Europe has grown by more than two thirds (Willer et al., 2020; Research Institute of Organic Agriculture (FiBL), 2020).

The size of the organic territory in 2018 varies significantly from one EU member state to another. The largest land areas are in Spain (2.24 million hectares or $16.2 \%$ of the total organic area of the EU), France (2.04 million hectares or $14.8 \%)$, Italy (1.95 million hectares or $14.1 \%)$ and Germany (1.52 million hectares or $11.0 \%)$. Together, they make up more than half (56.1\%) of the EU's organic land (Willer et al., 2020).

In general, the constant growth of the main indicators of the organic sector of the EU is associated with its legislative regulation, the presence of an influential protectionist policy, scientific approach and financial support (Milovanov, 2018).

Statistics on the number of organic animals are currently incomplete, but taking into account all available information, we can see the rapid development of the organic livestock sector in the EU. There are 53.62 million heads of poultry, 5.68 million heads of sheep, 4.76 million heads of cattle and 1.32 million heads of pigs are kept using organic technology in the EU member states. Most organic farms in EU member states are mixed with both organic and inorganic production (Willer et al., 2020; Eurostat, 2020).

The development of organic production in Ukraine dates back to the late 90s of the twentieth century. With significant potential for the development of organic production, representatives of the Ukrainian organic agribusiness are successfully mastering organic farming methods.

Agricultural lands of Ukraine, which are certified for organic production have increased from 269.9 thousand hectares to 309.1 thousand hectares over the last 10 years (by 39.2 thousand hectares or by 14.5\%) (Milovanov, 2018; Kaminska, 2020). As of 2018, the total area of agricultural land with organic status in Ukraine is 233.5 thousand hectares. There is a regional differentiation of land used by organic producers, which is expressed in a significant concentration of organic agricultural land in three regions of the country - Kherson (43.05 thousand hectares), Zhytomyr (30.94 thousand hectares) and Odessa regions (27.15 thousand hectares), where together almost half organic lands of Ukraine - 101.14 thousand hectares (Organic map of Ukraine, 2018).

The number of operators engaged in organic production in Ukraine during 2016-2019 increased by $41 \%$ (from 294 in 2016 to 501 in 2019), and over the last 10 years - by 324.5\% (from 118 to 501). At the same time, the total number of market operators in 2019 decreased by 44 operators in comparing with 2018 (from 635 to 597). However, according to the data of the last four years, the total number of operators of the organic products market in Ukraine has been growing by an average of $16.7 \%$ annually. Their number varies within the regions: from 5 in Chernivtsi region to 89 in Kyiv region (Domestic market of organic products of Ukraine, 2019-2020).

The results of estimating the ratio of growth rates between the number of organic agricultural producers and the area under organic land for the period of introduction of ERUs in Ukraine (Fig. 2) show that since 2003 there has been a constant outpacing growth of organic producers along with slow growth of organic agricultural areas, except 2013, when there was a sharp increase in land by $44.2 \%$ against $6.8 \%$ increase in the number of farms. However, after 2014 , a record increase in the number of producers in 2016 was recorded - by $71.4 \%$ with a decrease in organic areas by $7.2 \%$ compared to previous years, respectively. 2017 showed a sharp decline in both indicators: producers - by $15.6 \%$ and land - by $24.2 \%$. In 2018 , the situation in the sector stabilized somewhat - the number of producers increased by $64.8 \%$ and land areas increased by $7.0 \%$ compared to 2017 . 


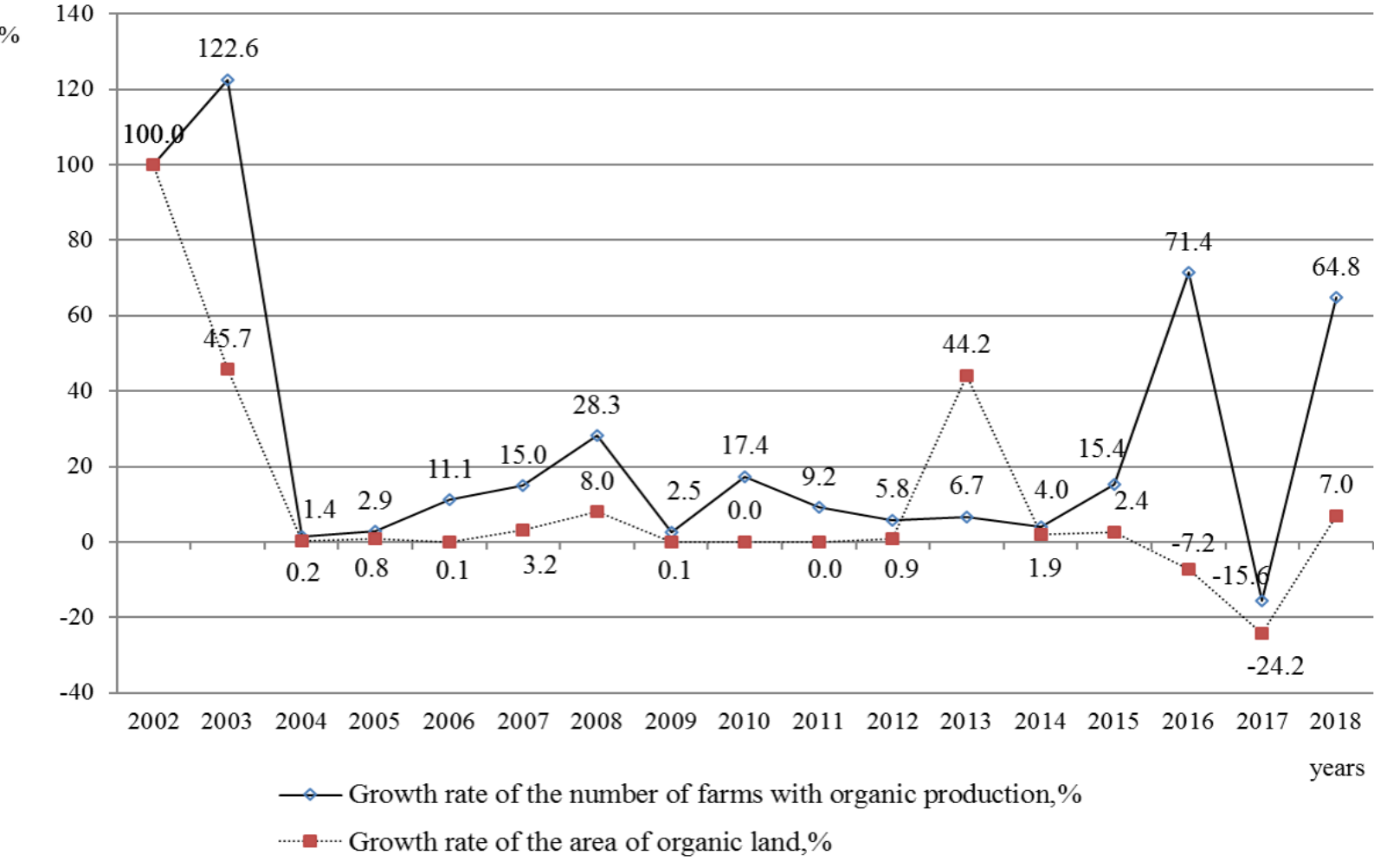

Fig. 2. Growth rates of the area of organic agricultural lands and the number of organic farms of Ukraine for $2002-2018$ Source: built by the authors based on statistics Research Institute of Organic Agriculture (FiBL)

In general, according to statistics, there is a faster growth in the number of organic producers compared to the slow growth of organic agricultural land. One of the main barriers, which is hindering the planned development of the Ukrainian market, is the unregulated legal regime of its operation. It in its turn causes cases of fraud of organic products, because of unfair competition from producers, certification authorities and traders. This unregulated legal regime affects the image of country and bona fide organic operators (Milovanov, 2018).

According to the official data of the Ukrainian certification body 'Organic Standard', which certifies almost 70\% of organic market operators, the peculiarity of economic activity of organic enterprises in Ukraine is the concentration of resources mainly on crop specialization. Livestock by organic standards is mainly represented in Kyiv, Zhytomyr, Vinnytsia, Volyn, Poltava, Chernihiv, Khmelnytsky, Odessa regions (Bernet et al., 2018; Bazaluk et al., 2020).

The predominance of the crop industry over the livestock industry in the organic agricultural sector is a global trend. However, the principles of organic production require a stable symbiosis of animal husbandry with crop production, which increases labor efficiency. Under development of livestock, first of all, leads to a lack of natural organic fertilizers and creates problems with nitrogen nutrition of crops (Bilyk, \& Tkachuk, 2015; Golub \& Marus, 2016).

In total, in the domestic market of our country (Fig. 3) in 2019, according to estimates, there were sold 7.35 thousand tons of organic products worth about 575 million UAH (equivalent to USD 24.3 million at the NBU exchange rate as of December 31 , 2019) (Domestic market of organic products of Ukraine, 2019-2020).

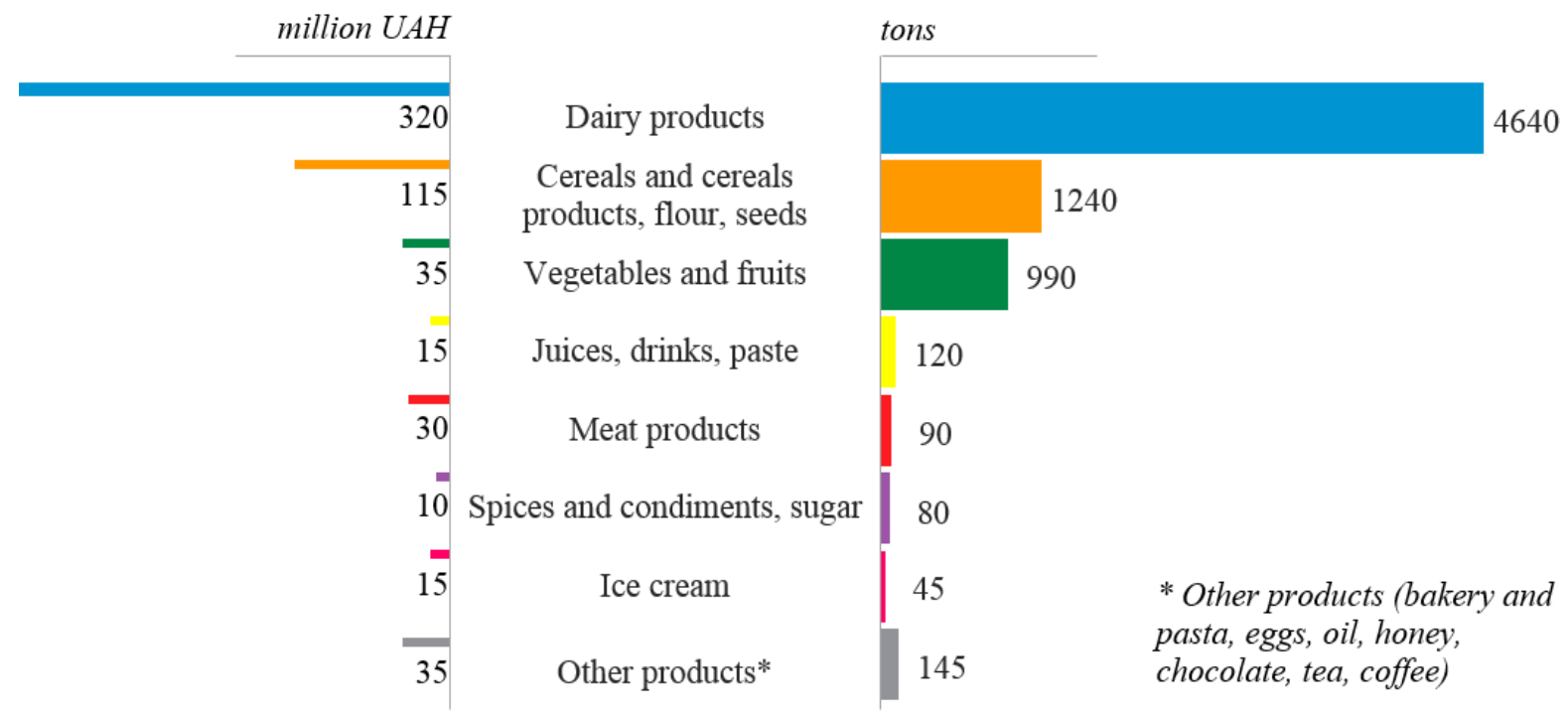

Fig. 3. Domestic market of organic products of Ukraine, 2019.

Source: built by the authors based on statistics Domestic market of organic products of Ukraine, exports and imports for 2019 , dated August 3, 2020 
As could be seen from Figure 3, the vast majority (63.13\%) of organic products, sold on the domestic market, were dairy products (4640 thousand tons), the share of grain and cereals, flour and seeds was $16.87 \%$ (1240 thousand tons), vegetables and fruit $13.47 \%$ (990 thousand tons), juices, beverages and pastes - 1.63\% (120 thousand tons), meat products - $1.22 \%$ ( 90 thousand tons), spices, condiments and sugar - 1.09\% (80 thousand tons), ice cream $-0.61 \%$ (45 thousand tons), and other organic products accounted for $1.97 \%$ (145 thousand tons).

Another feature of the national market of organic agricultural products is the supply of large organic companies of raw materials of plant origin to European consumers. The total revenue from sales of domestic organic products amounted to about 189 million US dollars according to a review of exports of Ukrainian organic products in 2019 (Organic market in Ukraine, 2020). The top 10 importers of domestic organic products in the EU include the Netherlands (31.4 million euros), Germany (20.5 million euros), Austria (11.7 million euros), Lithuania and Poland (10.3 million euros each), the United Kingdom (7.7 million euros), Italy (5.6 million euros), France (4.7 million euros), Romania (2.8 million euros) and Denmark (2.5 million euros) (Fig. 4) (Organic market in Ukraine, 2020).

\begin{tabular}{|c|c|c|}
\hline million USD & & thousand tons \\
\hline 37 & 1. Netherlands & 141 \\
\hline 14 & 2. Switzerland & 59.5 \\
\hline 34 & 3. USA & 50 \\
\hline 12 & 4. Lithuania & 47 \\
\hline 24 & 5. Germany & 42 \\
\hline 9 & 6. United Kingdom & 36.8 \\
\hline 14 & 7. Austria & 16.8 \\
\hline 12 & 8. Poland & 13.7 \\
\hline 3 & 9. Denmark & 10 \\
\hline 6.5 & 10. Italy & 8.6 \\
\hline
\end{tabular}

Fig. 4. Exports of Ukrainian organic products in 2019

Source: built by the authors based on statistics 'Organic Market in Ukraine' Newsletter dated February 12, 2020

Ukraine exports about 80 organic goods in total. According to the estimates of the certification body 'Organic Standard', in 2018 the main organic products (by volume) exported from Ukraine were: corn - 150.0 thousand tons, wheat - 90.0 thousand tons, soybeans - 60.2 thousand tons, seeds sunflower - 20.7 thousand tons, sunflower oil - 11.3 thousand tons, rapeseed - 8.6 thousand tons, apple juice (concentrate) - 5.6 thousand tons, blueberries (frozen) - 5.5 thousand tons, spelta - 5.1 thousand tons, fresh apples -4.5 thousand tons. In 2019, for the first time, about 800 tons of organic sugar produced from sugar were exported (Organic market in Ukraine, 2020). But in general, exports are characterized by dependence on three main commodity items: corn, wheat and soybeans, which account for almost more than half of the organic crop.

It could be said that the export of domestic organic products at premium prices stimulates the spread of organic technologies among Ukrainian producers at the present phase of development of the market of organic products.

\section{Legal regulation of the production of organic livestock products in accordance with the legislation of the European Union}

As of 2019 statistics of the global organic market show that out of 68 countries, which are developing organic production, only 18 countries regulates such activities, have formed national governing legislation and implemented it (Willer et al., 2020).

Standards of such influential organizations as IFOAM, entitled 'Basic Standards IFOAM for the Production and Processing of Organic Products' and the Food and Agriculture Organization of the United Nations, entitled 'Regulations of the Alimentarius Codex Commission on the Production, Processing, Labelling and Marketing of Organic Foods' (CAC/GL32-1999), have a recommendatory nature. (IFOAM, 2014). The priority in this process is to observe the principles that generally determine the worldviews of this method of management. On the basis of international standards and in accordance with the principles and goals allocated in them, the development of internal national standards of countries producing organic products.

The legal framework for the organic production sector in the EU is defined in the Council Regulation (EC) No $834 / 2007$ of 28 June 2007 on organic production and labelling of organic products and repealing Regulation (EEC) No 2092/91. Detailed rules for the implementation of this Regulation are set out in Commission Regulation (EC) No 889/2008 of 5 September 2008 laying down detailed rules for the implementation of Council Regulation (EC) No 834/2007 on organic production and labelling of organic products with regard to organic production, labelling and control and in the Commission Regulation (EC) No 1235/2008 of 8 December 2008 laying down detailed rules for implementation of Council Regulation (EC) No 834/2007 as regards the arrangements for imports of organic products from third countries. These regulations entered into force on 1 January 2009 and are currently in force to regulate the organic production sector, including the organic livestock sector in the EU (Council Regulation (EC) No 834/2007; Commission Regulation (EC) No 889/2008; Commission Regulation (EC) No 1235/2008).

At the same time, in some EU countries, for instance, in Germany, Bulgaria, France, national standards have been developed that regulate the rules and regulations of certification, taking into account both the requirements of EU regulations and 
geographical, climatic and socio-economic characteristics of their countries. In addition to national standards, some EU member states may have private regulations. They are developed in the framework of various associations of organic market participants (farmers' associations, unions, etc.). Private standards could be developed to ensure the competitive advantage of organic products in a particular area or to result in exacerbation of conflicts that arise between businesses of different sizes.

Council Regulation (EC) No 834/2007 describes the main objectives and principles of organic production, sets requirements for organic production, labelling, control and international trade in organic products. It consists of a preamble (which contains 40 points), 7 sections, 42 articles and 1 annex. The provisions of the preamble to this Regulation generally describe the content of the articles of the Regulation itself, giving a general idea of organic production. The first point of the preamble defines the essence of organic production from the point of view of its significance for society: 'Organic production is an overall system of farm management and food production that combines best environmental practices, a high level of biodiversity, the preservation of natural resources, the application of high animal welfare standards and a production method in line with the preference of certain consumers for products produced using natural substances and processes. The organic production method thus plays a dual societal role, where it on the one hand provides for a specific market responding to a consumer demand for organic products, and on the other hand delivers public goods contributing to the protection of the environment and animal welfare, as well as to rural development.

It should be noted that the preamble to Council Regulation (EC) No 834/2007 summarizes the content and requirements, that are directly related to organic livestock, namely: point (14) indicates the fundamental importance of animal husbandry for agriculture, its close relationship with the crop sector, point (15) indicates the general content of the rules of animal feeding, point (16) indicates the need for walking animals, point (17) discloses the general methods of keeping and treatment of animals, point (18) deals with the conditions of animal reproduction. It is important to add that point (17) of the Regulation states that The implementing rules for livestock production and aquaculture production should at least ensure compliance with the provisions of the European Convention for the Protection of Animals kept for Farming purposes'. At the same time, Article 1(2) of the Regulation states that 'the products of hunting and fishing for wild animals shall not be considered as organic production'. Article 2 defines organic production as one which is used for the purposes of the Regulation: 'organic production' means the use of the production method compliant with the rules established in this Regulation, at all stages of production, preparation and distribution'. It is specifically stated that «livestock production» 'means the production of domestic or domesticated terrestrial animals (including insects)'.

Title II describes the objectives of organic production, which determine the basic orientation of the organic sector to create a sustainable system of agricultural management, quality assurance of food and their wide range. Moreover, in some paragraphs of Title II, the main features of a sustainable management system, which targets organic production, are identified.

Article 4 of the Regulation contains the general principles of organic production, namely: (a) the appropriate proper design and management of biological processes based on ecological systems using natural resources which are internal to the system; (b) restrictions on the use of external inputs; (c) strict limitation on the use of chemically synthesised inputs to exceptional cases; (d) adaptation, where necessary, and within the framework of this Regulation, of the rules of organic production, taking account of sanitary status, regional differences in climate and local conditions, stages of development and specific husbandry practices. And Article 5 of the Council Regulation (EC) No 834/2007 sets out specific principles for organic production, which must also be applied to organic livestock, and some are directly related to it: (c) the recycling of wastes and by-products of plant and animal origin as input in plant and livestock production; (d) taking account of the local or regional ecological balance when taking production decisions; (g) the practice of site-adapted and land-related livestock production; (h) the observance of a high level of animal welfare respecting species-specific needs; (i) the production of products of organic livestock from animals that have been raised on organic holdings since birth or hatching and throughout their life; (j) the choice of breeds having regard to the capacity of animals to adapt to local conditions, their vitality and their resistance to disease or health problems; (k) the feeding of livestock with organic feed composed of agricultural ingredients from organic farming and of natural non-agricultural substances; (I) the application of animal husbandry practices, which enhance the immune system and strengthen the natural defence against diseases, in particular including regular exercise and access to open air areas and pastureland where appropriate; $(m)$ the exclusion of rearing artificially induced polyploid animals.

The objectives and principles are implemented through the general production rules of organic production set out in Title III. In their turn, the goals and principles guide and assist in the application of production rules in the implementation of practical activities, direct organic management to ensure its effective implementation.

The production rules include criteria for products and substances that could be used in organic production, such as fertilizers, feeds and food additives or products for cleaning and disinfection. Here, Articles 9 and 10 clearly state the prohibition of the use of genetically modified organisms (hereinafter - GMOs) and ionizing radiation in organic production in general, and in organic livestock in particular.

In addition to the general rules for organic production set out in Article 11, the basic rules for production for livestock set out in Article 14. These rules are appropriately structured and take into account: (a) the origin of the animals; b) husbandry practices and housing conditions; c) breeding; d) feed; e) disease prevention and veterinary treatment; f) cleaning and disinfection.

Article 16 separately defines the foodstuffs and substances used in agriculture and the criteria for their authorization. Council Regulation (EC) No 834/2007 provides general requirements for the specificity of organic production, which correspond to general and specific principles, detailing such principles by relevant production areas.

These rules are disclosed in detail in Commission Regulation (EC) No 889/2008 of 5 September 2008 laying down detailed rules for the implementation of Council Regulation (EC) No 834/2007 on organic production and labelling of organic products with regard to organic production, labelling and control. 
It should be noted that Article 22 of Council Regulation (EC) No 834/2007 provides with exceptions to the rules on organic production, in particular livestock. These ones are in Chapters 1 to 4 (meanwhile they should be kept down to a minimum and, by necessity, limited in time) with taking into account the objectives and principles set out in Title II, if they are need in order to: 1) ensure that organic production can be initiated or maintained on holdings confronted with climatic, geographical or structural constraints;

2) ensure access to feed, seed and vegetative propagating material, live animals and other farm inputs, where such inputs are not available on the market in organic form;

3) ensure access to ingredients of agricultural origin, where such ingredients are not available on the market in organic form;

4) solve specific problems related to the management of organic livestock;

5) use specific products and substances in the processing referred to in Article 19(2)(b) in order to ensure production of well established food products in organic form;

6) allow organic production to continue or recommence in the case of catastrophic circumstances;

7) use food additives and other substances as set outin Article 19(2)(b), or feed additives and other substances as set out in Article 16(1)(d) and such substances are available on the market only than produced by GMOs;

(8) use of food additives and other substances as set out in Article 19(2)(b) or feed additives as set out in Article 16(1)(d) is required on the basis of Community law or national law.

Chapter 6 of the Commission Regulation (EC) No 889/2008 contains exceptional production rules. Article 39 of this Regulation sets out the conditions of tethering of animals if the conditions of Article 22(2)(a) of Council Regulation (EC) No 834/2007 apply, which stipulate that 'competent authorities may authorise cattle in small holdings to be tethered if it is not possible to keep the cattle in groups appropriate to their behaviour requirements, provided they have access to pastures during the grazing period according to Article 14(2), and at least twice a week access to open air areas when grazing is not possible.'

Section 2 'Exceptions production rules' related to non-availability of organic farm inputs in accordance with Article 22(2)(b) of Council Regulation (EC) No 834/2007 contain articles specifying the use of non-organic animals (Article 42) and use of nonorganic feed (Article 43). Article 47 sets out the catastrophic circumstances for the application of Article 22(2)(f) of Council Regulation (EC) No 834/2007. Exceptions production rules must be approved by competent authority, individual operators shall keep documentary evidence of the use of the above exceptions.

\section{Legal regulation of production of organic livestock products in accordance with the national legislation of Ukraine}

For Ukraine, the development of the organic market is a priority in accordance with the 'Medium-Term Plan of Priority Actions of the Government until 2020', approved by the order of the Cabinet of Ministers of Ukraine from 03 April 2017 No 275-p and 'Concepts of development of farms and agricultural cooperation for 2018-2020', approved by the order of the Cabinet of Ministers of Ukraine from 13 September 2017 No 664-p. In particular, it provides incentives to increase the area of agricultural land where organic agricultural products are grown and/or produced and to stimulate the transition of farms to organic production (Order of the Cabinet of Ministers of Ukraine from 03.04.2017. № 275-p).

Organic production in Ukraine provides for compliance with all mandatory norms, rules and procedures, requirements for quality and safety of agricultural and food production, provided by current legislation (Adaptation to EU legislation, 2019). The obligatory component of the process of organic production is the procedure of inspection and certification (with special labelling), which confirms certain characteristics of the product, the operator receives an organic certificate, the product is given the status of 'organic'. This gives consumers confidence that the products for which they pay added value have organic quality (Airapetov et al., 2017) Domestic producers certify products according to foreign national or private standards due to the fact that at the beginning of the implementation of organic production in Ukraine, state standards to certificate of organic products have not been created (Bernet et al., 2018).

In the field of organic production and circulation of organic products for a long time there was no basic legal act that should regulate this activity. Although the first legislative activity in this direction dates back to year 2003 with the active participation of the Swiss Agency for Development and Cooperation, namely the 'Law of Ukraine On Production and Circulation of Organic Agricultural Products and Raw Materials' of 03 September 2013 (Law, 2018) came into force only in January 2014 - when 182 producers of organic products were already officially registered in Ukraine, and the area of certified agricultural land was 400.0 thousand hectares.

However, the mechanism for implementing the provisions of this Law has not been enshrined in all necessary regulations and orders. As of 2016, the Cabinet of Ministers of Ukraine adopted only 7 out of the 23 regulatory legal acts provided for by this Law (Ignatenko, 2020). The law also contained a number of inconsistencies with the current legislation of Ukraine in other areas, which made it impossible to apply in practice (Airapetov et al., 2017).

The legislative base of Ukraine on the production and circulation of organic products needed significant improvement after the signing on 27 June 2014 of the economic and sectoral parts of the Association Agreement between the European Union and its Member States, of one part, and Ukraine, of the other part (hereinafter - the Agreement). According to the Association Agreement, Ukraine is obliged to implement the EU legal acts into national legislation (Association agreement between the European Union and its Member States, of the one part, and Ukraine, of the other part, 2014; Milovanov, 2018).

In the Association Agreement between Ukraine and the European Union in Article 403 of Chapter 17 'Agriculture and Rural Development' states that 'the Parties shall cooperate to promote agricultural and rural development, in particular through gradual approximation of policies and legislation'. In Article 404(c) it is said about necessity to 'promoting modern and sustainable agricultural production, respectful of the environment and of animal welfare, including extension of the use of organic production methods and the use of biotechnologies, inter alia through the implementation of best practices in those fields'. 
In particular, it is important for the Ukrainian organic sector that Annex XXXVIII to Chapter 17 'Agriculture and Rural Development' of Chapter $V$ 'Economic and Sectoral Cooperation' of the Agreement states that 'EU regulations, directives, decisions, recommendations and communications contained in annexes, are part of the legal standards considered by the Ukrainian Party in the gradual approximation of legislation on a particular sector or product'. In accordance with Annex XXXVIII to Chapter 17 'Agriculture and Rural Development' of Section V 'Economic and Sectoral Cooperation' of the Agreement, the following legal documents must be taken into account when regulating the development of organic farming:

$\checkmark$ Council Regulation (EC) No 834/2007 of 28 June 2007 on organic production and labelling of organic products and repealing Regulation (EEC) No 2092/91;

$\checkmark$ Commission Regulation (EC) No 889/2008 of 5 September 2008 laying down detailed rules for the implementation of Council Regulation (EC) No 834/2007 on organic production and labelling of organic products with regard to organic production, labelling and control;

$\checkmark$ Commission Regulation (EC) No 1235/2008 of 8 December 2008 laying down detailed rules for implementation of Council Regulation (EC) No 834/2007 as regards the arrangements for imports of organic products from third countries.

According to the comments of organic market participants, the Law of Ukraine 'On Production and Circulation of Organic Agricultural Products and Raw Materials' dated 03 September 2013 No 425-VII did not comply with the legislation of the European Union. In view of this, there is an objective need to improve the legal framework with the aim to regulate the production, circulation and labelling of organic products.

In 2016, the Ministry of Agrarian Policy and Food of Ukraine initiated and developed in cooperation with local and international partners a new version of the draft Law of Ukraine 'On Basic Principles and Requirements for Organic Production, Circulation and Labelling of Organic Products' (registered in the Verkhovna Rada of Ukraine under No 5448 dated 24 November 2016).

The purpose of the Law, as noted in the explanatory note to it, is both to improve the principles of legal regulation of organic production, circulation and labelling of organic products, and to adapt Ukrainian legislation to European Union legislation in this area.

According to experts, in the adopted Law of Ukraine 'On Basic Principles and Requirements for Organic Production, Circulation and Labelling of Organic Products' dated 10 July 2018 No 2496, which entered into force on August 2, 2018 and has been applyingfrom 2 August 2019 is provided the elimination of shortcomings of the previous law, in particular the contradiction of current regulations governing organic production in the EU in terms of vagueness of the principles on the rules of organic production and circulation of organic products, certification of organic production (state supervision control) over the activities of organic market operators. In particular, according to the explanatory note to the Law: 'During the finalization, the draft Law was supplemented by new principles of Commission Regulation (EC) No 889/2008, which were introduced into the Commission Regulation after the draft law No 5448 was registered'.

The mechanism of implementation of the norms of this Law is provided by 12 normative acts (resolutions of the Cabinet of Ministers of Ukraine and orders of the relevant Ministries of Ukraine).

As of November 2020, the Cabinet of Ministers of Ukraine has already approved three important resolutions:

1. 'On approval of the Procedure (detailed rules) of organic production and circulation of organic products' dated 23 October 2019 No 970 (according to Article 13 of the Law).

2. 'On approval of the Procedure for maintaining the State Register of operators engaged in production in accordance with the legislation in the field of organic production, circulation and labelling of organic products, the State Register of certification authorities in the field of organic production and circulation of organic products, the State Register of organic seeds and planting material' dated 12 February 2020 No 87 (according to Article 31 of the Law).

3. 'On approval of the Procedure for certification of organic production and/or circulation of organic products and amendments to the resolution of the Cabinet of Ministers of Ukraine dated 23 October 2019 No 970' dated 21 October 2020 No 1032 (according to Articles 24, 27 of the Law of Ukraine).

In addition, the profile ministries also adopted the Order 'On approval of the List of substances (ingredients, components) that may be used in the process of organic production and which are permitted to use in maximum permissible quantities' dated 09 June 2020 No 1073 (according to Articles 14, 23 the Low of Ukraine), Order 'On approval of the state logo for organic products' dated 22 February 2019 No 67, amended Edition dated 14 August 2020 (according to Article 11 of the Low of Ukraine). These and other legal regulations detail the requirements, procedure and features of certification organic agricultural products and aimed at streamline the production and marketing of organic products. Currently, most regulations - 9 the ones out of 12 as of 02 November 2020 have been already adopted.

Approval of the whole set of normative legal acts will have create a national system of integral legislative regulation in the organic sector of Ukraine. Since the entry into force of the Law of Ukraine 'On Basic Principles and Requirements for Organic Production, Circulation and Labelling of Organic Products', domestic producers are required to be certified in accordance with the 'Procedure (detailed rules) for organic production and circulation of organic products' adopted in Ukraine.

This mentioned above Law provides for measures aimed at the development of the domestic market, namely: additional labelling of organic products with the state logo and the label 'organic product'. These measures together with other labelling protect it from counterfeiting. Moreover, economic mechanisms to prevent counterfe it organic products is proposed.

In particular, the Law of Ukraine 'On Basic Principles and Requirements for Organic Production, Circulation and Labelling of Organic Products' defines the basic principles and requirements for organic production, circulation and labelling of organic products, principles of legal regulation of organic production, circulation of organic products and functioning of organic products market, basics of activity of central executive authorities, subjects of the market of organic products and directions of the state policy in the specified spheres. 
According to Article 3 of the Law, organic production, circulation and labelling of organic products in Ukraine is regulated by this Law and law regulations issued in accordance with it, legislation on safety and certain indicators of food quality, state control over compliance with legislation on food, feed, by-products products of animal origin, animal health and welfare, plant quarantine, plant protection, seed and nursery protection, veterinary medicine, beekeeping, aquaculture, viticulture and winemaking, protection and use of flora and fauna, and land, forest, environmental and other special legislation governing relations in this area.

Article 1 defines the term 'organic production', which refers to certified activities related to the production of agricultural products, including all stages of the technological process, namely primary production (including harvesting), preparation, processing, mixing and related procedures, filling, packaging, processing, recovery and other changes in the state of production, which is carried out in compliance with the requirements of the legislation in the field of organic production, circulation and labelling of organic products.

Article 1 of the Law also defines the term 'organic livestock' - 'organic production related to the keeping, breeding (production) of farm animals (including poultry and insects) and products for the production of products of animal origin'. 'Organic animals' - animals (including birds and insects) raised as a result of organic livestock. Article 2 specifies that 'this Law is not applied to ... products of hunting and fishing taken from the natural environment'. And in Article 13, organic livestock (including poultry, beekeeping) is defined as a branch of organic production.

This Law is compliance whith norms of Council Regulation (EC) No 834/2007 to the greater extent. However, there are areas that are not in the national legislation of Ukraine, they are needed to be researched and discussed.

It should be noted that Article 6 of the Law defines 10 principles on which the state policy in the field of organic production, circulation and labelling of organic products is based. 8 principles have the main content to create conditions for the state to ensure formal and organisational functioning of the organic sector production and the relevant market. Two principles, namely the principle of 'sustainable development - development of organic production and the market of organic products to meet the needs of the current generation taking into account the interests of future generations' and the principle of 'compliance with environmental safety requirements in organic production and/or circulation of organic products' the process of organic production and circulation of organic products in the livestock sector, which is supported by state policy in this area. However, these principles do not fully disclose the content of the process of production and circulation of organic products, its characteristics, using indirect general concepts of 'sustainable development' and 'environmental safety', which do not directly define this process. In the Article 1(1) of this Law there are no definitions of these concepts. The Laws referred to this Law in the Article 1(2) concerning the use of concepts do not define these concepts either.

The Article 6(2) defines the directions of state policy directly related to the process of production of organic livestock products, namely: "humane treatment of animals by providing living conditions for animals that meet their biological, species and individual characteristics'; 'ensuring genetic safety, biological diversity and rational use of natural resources and their reproduction'; 'ensuring environmental safety during organic production'. Such directions state the corresponding state in the field of organic production, in particular in the field of animal husbandry, but do not reveal and do not explain the peculiarity of its achievement.

\section{Conclusions}

Our comparative legal analysis of Ukrainian and the EU legislation in the field of production of organic livestock products revealed certain inconsistencies of the current Ukrainian legislation with the relevant norms of EU law. Taking into account the requirements of the State Program for Adaptation of Ukrainian Legislation to the Legislation of the European Union approved by the Law of Ukraine of 18 March 2004 No 1629-IV and the Association agreement between the European Union and its Member States, of the one part, and Ukraine, of the other part, we offer recommendations that would help improve the legal regulation of organic livestock production in Ukraine:

1. Taking into account the content of paragraph 5 of the preamble of Council Regulation (EC) No 834/2007 to supplement Article 1 of the Law of Ukraine 'On Basic Principles and Requirements for Organic Production, Circulation and Labelling of Organic Products' with clear definitions of objectives and principles for organic production namely, to 'promote transparency and consumer confidence, as well as a harmonized perception of the concept of organic production'.

Defining the principles of organic production in the livestock sector is important for its clear labelling and separation from inorganic production in the livestock sector. This would ensure fair competition and reduce confusion among consumers about the characteristics of organic livestock production and provide a clear picture of organic livestock products. Moreover, the very title of the Law contains the concept of 'principles of organic production', including organic animal husbandry, but the detailed content of the actual principles is missing in this Law.

2. Taking into account the content of Article 14(1d)(v) of Council Regulation (EC) No 834/2007, the ninth paragraph of the Article 14(2) of the Law of Ukraine 'On Basic Principles and Requirements for Organic Production, Circulation and Labelling of Organic Products' should be worded in follows edition: 'growth promoters and synthetic amino-acids'.

3. Taking into account the content of Article 14(1 b)(ii) and 14(1 b)(viii) of Council Regulation (EC) No 834/2007, to edit the second paragraph of the 2 point of Article 19(1) of the Law of Ukraine 'On Basic Principles and Requirements for Organic Production, Circulation and labelling of organic products' in follows: 'husbandry practices, including stocking densities, and housing conditions shall ensure that the developmental, physiological and ethological needs of animals are met. Any suffering, including mutilation, shall be kept to a minimum during the entire life of the animal, including at the time of slaughter'.

4. Taking into account the content of Article 14(1 b)(iii) of Council Regulation (EC) No 834/2007, add a new paragraph to point 2 of Article 19(1) of the Law of Ukraine “On Basic Principles and Requirements for Organic Production, Circulation and labelling 
of organic products' of the such content: 'the livestock shall have permanent access to open air areas, preferably pasture, whenever weather conditions and the state of the ground allow'.

5. Taking into account the content of Article 14(1 b)(V) of Council Regulation (EC) No 834/2007, add to point 2 of Article 19(1) of the Law of Ukraine 'On Basic Principles and Requirements for Organic Production, Circulation and Labelling of Organic Products' a new paragraph of the such content: 'organic livestock shall be kept separate from other livestock. However, grazing of common land by organic animals and of organic land by non-organic animals is permitted under certain restrictive conditions'. 6. Taking into account the content of Article 14(1d)(i) of Council Regulation (EC) No 834/2007, add to point 2 of Article 19(1) of the Law of Ukraine 'On Basic Principles and Requirements for Organic Production, Circulation and Labelling of Organic Products' a new paragraph of the such content: 'primarily obtaining feed for livestock from the holding where the animals are kept or from other organic holdings in the same region '.

7. Taking into account the content of Article 14(6) of Commission Regulation (EC) No 889/2008, add to point 2 of Article 19(1) of the Law of Ukraine 'On Basic Principles and Requirements for Organic Production, Circulation and Labelling of Organic Products' and point 20 of the Procedure (detailed rules) of organic production and circulation of organic products, which have been approved by the Resolution of the Cabinet of Ministers on 23 October 2019 No 970, a new paragraph of the such content: 'Open air for poultry shall be mainly covered with vegetation'.

8. Taking into account the content of point 14 of the preamble to Council Regulation (EC) No 834/2007, point 8 of the preamble and Article 16 of Commission Regulation (EC) No 889/2008, to supplement Article 14 of the Law of Ukraine 'On Basic Principles and Requirements for Organic Production, Circulation and labelling of organic products' whith the fourth part of the such content: 'Landless livestock production, by which the operator of the livestock does not manage agricultural land and/or has not established a written cooperation agreement with another operator, is prohibited.'.

9. Taking into account the content of point 14 of the preamble to Council Regulation (EC) No 834/2007, point 8 of the preamble and Article 16 of Commission Regulation (EC) No 889/2008 to supplement the Procedure (detailed rules) of organic production and circulation of organic products approved by the Cabinet Ministers dated 23 October 2019 No 970, with point 3-1 of the such content: 'Landless livestock production, by which the operator of the livestock does not manage agricultural land and/or has not established a written cooperation agreement with another operator, is prohibited'.

\section{References}

Adaptation to EU legislation: focus on small and medium-sized agricultural producers. (2019). Basic research. Kyiv. Available from: http://www.dossier.org.ua/adaptaciya-do-zakonodavstva-ies-u-fokusi-mali-ta-seredni-virobniki-agrarnoyi-produkciyi-2evidannya

Airapetov, M., Georgian, I., \& Simagina, A. (2017). Green Paper. Market of production and circulation of organic products. Office of effective regulation BRDO. Kiev.

Association agreement between the European Union and its Member States, of the one part, and Ukraine, of the other part. OJ L 161, 29.05.2014, 3-2137. Available from: https://eur-lex.europa.eu/legal-content/EN/TXT/PDF/.uri=CELEX:22014A0529(01)\&from=EN

Bazaluk, O., Yatsenko, O., Zakharchuk, O., Ovcharenko, A., Khrystenko, O., \& Nitsenko, V. (2020) Dynamic Development of the Global Organic Food Market and Opportunities for Ukraine. Sustainability, 12, 6963. doi:10.3390/su12176963

Bernet, T., Home, R., \& Hasiuk, O. (2018). Socio-economic study of the development of the organic market and sector in Ukraine. Available from: https://orgprints.org/35335/1/Socio-economic-study_UA_Dec2018_published.pdf

Bilyk, R. I., \& Tkachuk, S. A. (2015). Requirements for veterinary care of organic dairy farms. Veterinary medicine of Ukraine, 3 , 29-33. Available from: http://uww.irbis-nbuv.gov.ua/cgi-

bin/irbis nbuv/cgiirbis 64.exe?Z21ID=\&121DBN=UJRN\&P21DBN=UJRN\&S21STN=1\&S21REF=10\&S21FMT=njuu all\&C21COM=S\&S21CNR $=20 \& S 21$ P01 $=0 \& S 21$ P02=0\&S21COLORTERMS=0\&S21P03=I=\&S21STR=\%D0\%9615159\%2F2015\%2F3

CAC/GL32-1999. Regulations of the Alimentarius Code Commission on the Production, Processing, Labeling and Marketing of Organic Foods.

Council Regulation (EC) No 834/2007 of 28 June 2007 on organic production and labelling of organic products and repealing Regulation (EEC) No 2092/91. OJ L 1 89, 20.7.2007, 1-23. Available from: http://data.europa.eu/eli/reg/2007/834/oj

Commission Regulation (EC) No 889/2008 of 5 September 2008 laying down detailed rules for the implementation of Council Regulation (EC) No 834/2007 on organic production and labelling of organic products with regard to organic production, labelling and control. OJ L 250, 18.9.2008, 1-84. Available from: http://data.europa.eu/eli/reg/2008/889/oj.

Commission Regulation (EC) No 1235/2008 of 8 December 2008 laying down detailed rules for implementation of Council Regulation (EC) No 834/2007 as regards the arrangements for imports of organic products from third countries. OJ L 334, 12.12.2008, 25-52. Available from: https://eur-lex.europa.eu/legal-content/EN/ALL/?uri=CELEX\%3A32008R1235

Dayoub, M. \& Korpela, T. (2019). Trends and challenges in organic farming in the European Union, International Journal of Agricultural Technology, 15(4), 527-538.

Domestic market of organic products of Ukraine, exports and imports for 2019, from 03.08.2020. Available from: https://agropolit.com/infographics/view/95

Escribano, A. J. (2016). Organic livestock farming-challenges, perspectives, and strategies to increase its contribution to the agrifood system's sustainability-a review. Organic farming-a promising way of food production'. (Ed. P. Konvalina) pp. 229-260.

Eurostat. Available from: https://ec.europa.eu/eurostat/data/database?node_code=org. 
Golub, G. A., \& Marus, O. A., (2016). The concept of production of environmentally friendly crop and livestock products. Scientific Bulletin of the National University of Life and Environmental Sciences of Ukraine. Series: Engineering and energy of agroindustrial complex, 254, 361-372. Available from: http://journals.nubip.edu.ua/index.php/Tekhnica/article/viewFile/7666/7366

Husic-Mehmedovic, M., Arslanagic-Kalajdzic, M., Kadic-Maglajlic, S., \& Vajnberger, Z. (2017). Live, Eat, Love: life equilibrium as a driver of organic food purchase. British Food Journal, 119(7), 1410-1422. doi: 10.1108/BFJ-07-2016-0343

Ignatenko, I. (2020). Legal aspects of development of organic agriculture in Ukraine in the context of European integration. Economics of Agriculture, 67(3). doi: 10.5937/ekoPolj2003973।

Information web portal OrganicInfo. Infographics. Import of Ukrainian organic products to the EU (2019). Available from: https://organicinfo.ua/ru/infographics/import-ukrains-koi-orhanichnoi-produktsii-v-yes-2019-rik-krainy/

IFOAM (2014). The IFOAM Norms for organic production and processing. IFOAM, Germany.

Kaminska, A. I. (2020). World experience in the development of organic production. Agrosvit, 17-18, 23-27.

Law of Ukraine of 10.07.2018. № 2496-VIII. On the basic principles and requirements for organic production, circulation and labeling of organic products. Available from: https://zakon.rada.gov.ua/laws/show/2496-19\#Text

Milovanov, E. B. (2019). Development of normative-legal regulation of organic agricultural production in Ukraine. Bulletin of Kremenchug National University named after Mykhailo Ostrogradsky, 3, 97-106. doi: 10.30929/1995-0519.2019.3.97-10

Milovanov, E. B. (2018). Legal bases of regulation of organic production in the EU countries. Economics of agro-industrial complex, 5, 117-125. Available fronmttp://organic.com.ua/wp-content/uploads/2019/10/pravovi zasady regulyuvannya organic eu.pdf

Nazarenko, S. M., Paliy, A. P., Berezovskiy, A. V., Fotin, A. I., Fotin, O. V., Petrov, R. V., Kasianenko, O. I., Lazorenko, L. N., Negreba, J. V., Palii, A. P., \& Rebenko, H. I. (2020). Improving the sanitary condition of pond bed by forage grass cultivation. Ukrainian Journal of Ecology, 10(2), 368-374. doi: 10.15421/2020_111

Order of the Cabinet of Ministers of Ukraine from 03.04.2017. № 275-p. On approval of the medium-term plan of priority actions of the Government until 2020. Available from: https://zakon.rada.gov.ua/laws/show/275-2017-p\#Text

Order of the Cabinet of Ministers of Ukraine from 13.09.2017. № 664-p. On approval of the Concept of development of farms and agricultural cooperation for 2018-2020. Available from: https://zakon.rada.gov.ua/laws/show/664-2017-p\#Text

Organic map of Ukraine, as of December 31, 2018. Available from: https://organicinfo.ua/infographics/organicmap2018/

Organic market in Ukraine. Information bulletin dated 12.02.2020. Available from: https://organicinfo.ua/wpcontent/uploads/2020/02/UAOrganic fact sheet 2020-UA-1.pdf

Paliy, A. P., Stegniy, B. T., Palii, A. P., Rodionova, K. O., Bogatko, N. M., Vashchyk, Ye. V., Sakhniuk, N. I., Ovcharenko, H. V., Dudus, T. V., Ihnatieva, T. M., \& Kovalenko, L. V. (2020a). Microstructural analysis of sausage quality. Ukrainian Journal of Ecology, 10(2), 404-409. doi : 10.15421/2020_115

Paliy, A. P., Zavgorodniy, A. I., Stegniy, B. T., \& Palii, A. P. (2020b). Scientific and methodological grounds for controlling the development and use of disinfectants. Monograph. Kharkiv: Miskdruk (in Ukrainian)

Reganold, J. P., \& Wachter, J. M. (2016). Organic agriculture in the twenty-first century. Nature plants, 2(2), 1-8.

Research Institute of Organic Agriculture (FiBL). (2020). Statistics. Available from: https://statistics.fibl.org/index.html

Rodionova, K., Steshenko, V., \& Yatsenko, I. (2020). Approximating Ukraine's laws to those of the European Union concerning meat and meat products cold chain. Journal of Advanced Research in Law and Economic, 9(3), 978-992. doi: 10.14505/jarle.v11.3(49).34

Seufert, V., Ramankutty, N., \& Mayerhofer, T. (2017). What is this thing called organic?-How organic farming is codified in regulations. Food Policy, 68, 10-20. doi: 10.1016/j.foodpol.2016.12.009.

Ulko, Y. (2019). Evaluation of economic efficiency of innovations in organic farming. Agricultural and Resource Economics: International Scientific E-Journal, 5(3). doi: 10.22004/ag.econ.293989

Willer, H., Schlatter, B., Trávníček, J., Kemper, L., \& Lernoud, J. (2020). The world of organic agriculture. Statistics and emerging trends 2020. The world of organic agriculture. Statistics and emerging trends 2020. https://shop.fibl.org/chde/5011organic-world-2020.html

\section{Citation:}

Rodionova, K.O., Nihmatova, O.S., Khimych, M.S., Steshenko, V.M., Broshkov, M.M., Paliy, A.P., Yatsenko, I.V., Palii, A.P. (2020). Comparative and legal analysis of the legislation of Ukraine and the European Union in the field of organic production of livestock.

Ukrainian Journal of Ecology, 106), 280-290.

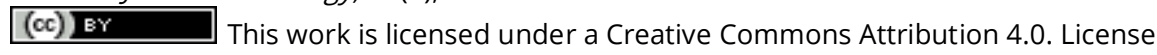

